\title{
Measurement technique for the determination of photolyzable chlorine and bromine in the atmosphere
}

\author{
G. A. Impey, P. B. Shepson,' D. R. Hastie, L. A. Barrie ${ }^{2}$ \\ Department of Chemistry and Centre for Atmospheric Chemistry, York University, Toronto, Ontario, Canada
}

\begin{abstract}
A technique has been developed to enable measurement of photolyzable chlorine and bromine at trace levels in the troposphere. In this method, ambient air is drawn through a cylindrical flow cell, which is irradiated with a Xe arc lamp. In the reaction vessel of the photoactive halogen detector (PHD), photolytically active molecules $\mathrm{Cl}_{\mathrm{p}}$ (including $\mathrm{Cl}_{2}, \mathrm{HOCl}$, $\mathrm{ClNO}, \mathrm{ClNO}_{2}$, and $\mathrm{ClONO}_{2}$ ) and $\mathrm{Br}_{\mathrm{p}}$ (including $\mathrm{Br}_{2}, \mathrm{HOBr}, \mathrm{BrNO}, \mathrm{BrNO}_{2}$, and $\mathrm{BrONO}_{2}$ ) are photolyzed, and the halogen atoms produced react with propene to form stable halogenated products. These products are then sampled and subsequently separated and detected by gas chromatography. The system is calibrated using low concentration mixtures of $\mathrm{Cl}_{2}$ and $\mathrm{Br}_{2}$ in air from commercially available permeation sources. We obtained detection limits of $4 \mathrm{pptv}$ and 9 pptv as $\mathrm{Br}_{2}$ and $\mathrm{Cl}_{2}$, respectively, for $36 \mathrm{~L}$ samples.
\end{abstract}

\section{Introduction}

The episodic destruction of ground level ozone in the Arctic at sunrise is a phenomenon that has been observed for many years. With the onset of polar sunrise, ozone levels are often observed to drop from a background concentration of $\approx 40 \mathrm{ppbv}$ to almost zero on a timescale of a day or less [Barrie et al., 1988] for periods of 1-10 days. It has been suggested that the extremely rapid destruction of near-surface ozone is associated with bromine and chlorine atom chemistry [Barrie et al., 1988; McConnell et al., 1992; Jobson et al., 1994]. While the primary source of the halogen atoms is still under investigation, current information has led to the hypothesis that the heterogeneous release of photochemically active forms of chlorine and bromine from sea salt aerosol, and/or recycling of adsorbed $\mathrm{HBr}$ and $\mathrm{HOBr}$ [Fan and Jacob, 1992] may be responsible. Some of the processes thought to be responsible, particularly as sources for bromine atoms, are as follows: photolysis of $\mathrm{BrNO}$ or $\mathrm{BrNO}_{2}$ formed by reaction of $\mathrm{NO}_{2}$ or $\mathrm{N}_{2} \mathrm{O}_{5}$, respectively, with sea salt aerosol [Finlayson-Pitts et al., 1989, 1990]; photochemical release of $\mathrm{Br}_{2}$ from $\mathrm{Br}^{-}$in the snow pack [McConnell et al., 1992]; or the recycling process of $\mathrm{HBr}, \mathrm{HOBr}$, and $\mathrm{BrONO}_{2}$ on acidic aerosol to release $\mathrm{Br}_{2}$ [Fan and Jacob, 1992; Abbatt, 1994] along with $\mathrm{BrCl}$ [Abbatt, 1994; Vogt et al., 1996]. These mechanisms can be tested with appropriate measurements of the precursors and/or the halogenated products.

To improve our understanding of which processes may be important with respect to halogen atom chemistry in the troposphere, reliable measurement methods for photolytically active sources of chlorine atoms (e.g., $\mathrm{Cl}_{2}$ and $\mathrm{HOCl}$ ) and bromine atoms (e.g., $\mathrm{Br}_{2}$ and $\mathrm{HOBr}$ ) are clearly needed. Although a method has been reported that enables measurement of $\mathrm{Cl}_{2}$ [Keene et al., 1993; Pszenny et al., 1993], this is not the case for $\mathrm{Br}_{2}$. There have, as yet, been no measurements of $\mathrm{Br}_{2}$

\footnotetext{
${ }^{1}$ Now at Departments of Chemistry and Earth and Atmospheric Sciences, Purdue University, West Lafayette, Indiana.

${ }^{2}$ Also at Atmospheric Environment Service, Toronto, Ontario, Canada.

Copyright 1997 by the American Geophysical Union.
}

Paper number 97JD00850.

0148-0227/97/97JD-00850\$09.00 (or $\mathrm{Cl}_{2}$ ) in the Arctic, largely as a result of the lack of suitable analytical methodologies. This paper reports the development of a measurement technique for the determination of rapidly photolyzing chlorine (referred to here as $\mathrm{Cl}_{\mathrm{p}}$ ) and bromine $\left(\mathrm{Br}_{\mathrm{p}}\right)$ species at parts per trillion by volume (pptv) mixing ratios in the atmosphere. Impey et al. [this issue] discuss the results observed from a field study conducted in the Canadian high Arctic at Alert, Northwest Territories, from mid-February through mid-April as part of the Polar Sunrise Experiment (PSE) 1995.

\section{Methodology}

The principle of the photoactive halogen detector is to rapidly photolyze the ambient halogen-containing compound to release a halogen atom(s). The halogen atom(s) then reacts with a scavenger hydrocarbon molecule to produce a stable halogenated product that can be collected and measured. A schematic of the system is shown in Figure 1. The sample air is drawn through a length of $\sim 7 \mathrm{~m}, 0.635 \mathrm{~cm}$ O.D. heavy walled TFE-Teflon tubing at $1 \mathrm{~L} / \mathrm{min}$ to an in-line filter (Zitex $47 \mathrm{~mm}$ Teflon extra-fine, contained in a PFA-Teflon filter holder) that removes fine aerosol from the air stream. Tests indicate that $>94 \%$ of both $\mathrm{Cl}_{2}$ and $\mathrm{Br}_{2}$ pass through the inlet line assembly. Small flows $(20 \mathrm{~mL} / \mathrm{min})$ of propene $\left(\mathrm{C}_{3} \mathrm{H}_{6}\right)$ and nitric oxide (NO) from $100 \mathrm{ppm}$ mixtures in nitrogen are added to the inlet air stream resulting in concentrations of $\sim 0.5 \mathrm{ppm}$ for both within the photoactive halogen detector (PHD) reaction vessel. The sample air passes through a $2 \mathrm{~L}$ volume cylindrical pyrex vessel, $52 \mathrm{~cm}$ in length (sample outlet $17 \mathrm{~cm}$ from the end of the cell) with an outer diameter of $7.0 \mathrm{~cm}$ and a $0.159 \mathrm{~cm}$ thick borosilicate glass window secured on either end. This allows transmission of the full range of visible light, decreasing to a transmission of $10 \%$ at $280 \mathrm{~nm}$. Light from a $150 \mathrm{~W}$ xenon arc lamp (A1010 lamp housing, LPS-220 power supply, PTI Inc.), situated at one end of the cylindrical cell, is collimated by a fused silica lens (01LQT011 PCC, $D=50 \mathrm{~mm}, F L=200 \mathrm{~mm}$ ) and passed through the cell. Photolyzable chlorine and bromine compounds will yield free $\mathrm{Cl}$ and $\mathrm{Br}$ atoms which react rapidly with the added propene, in the presence of nitric oxide, to produce chloroacetone and bromoacetone as stable products. $\mathrm{Cl}$ and $\mathrm{Br}$ atoms can react via three possible pathways, as shown below: 


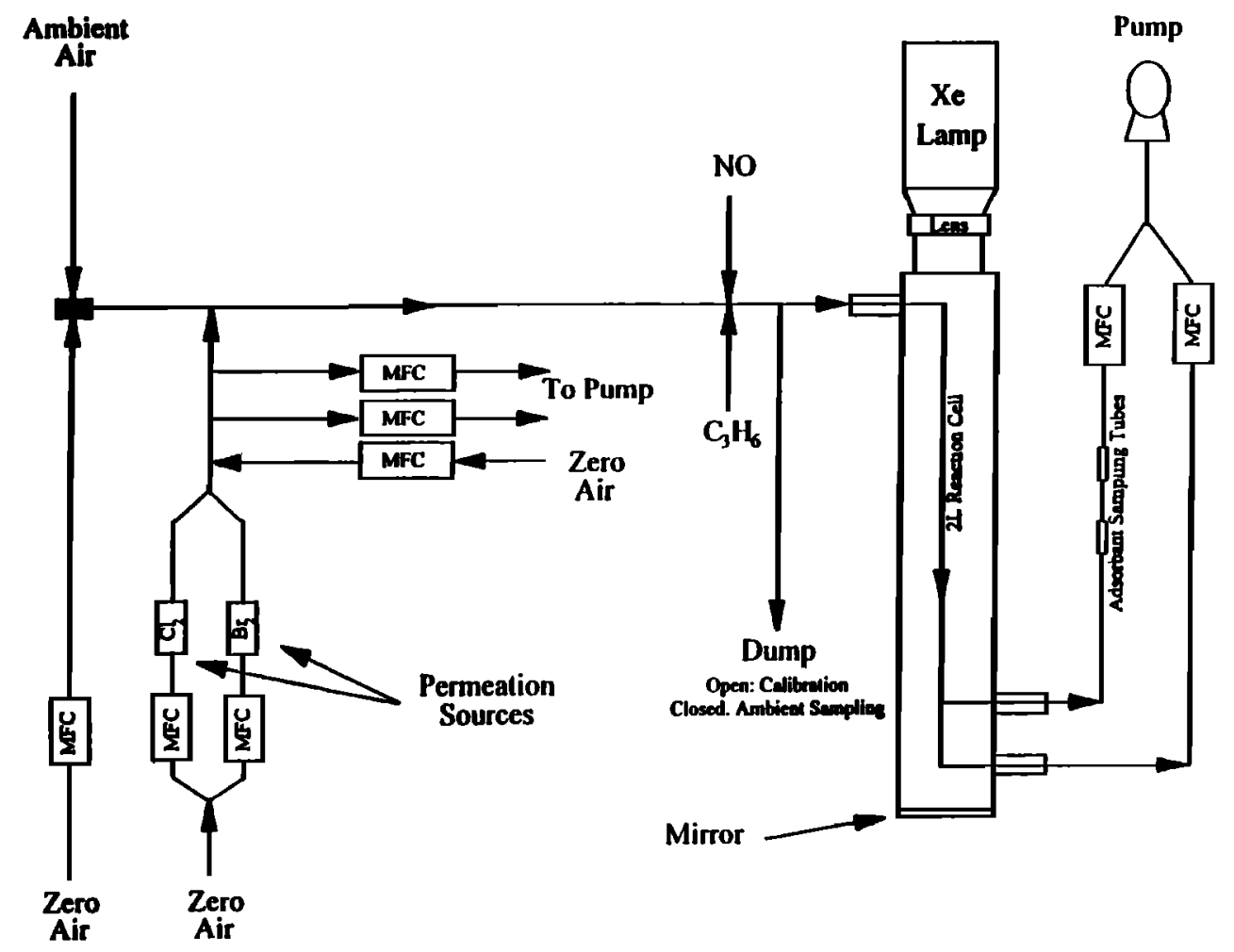

Figure 1. Schematic diagram of the photoactive halogen detector (PHD). (MFC, mass flow controller).

\begin{tabular}{|c|c|c|c|c|c|}
\hline (R1a) & $\mathrm{X}$ & + & $\mathrm{CH}_{2}=\mathrm{CHCH}_{3}$ & $\rightarrow$ & $\mathrm{XCH}_{2} \mathrm{CHCH}_{3}$ \\
\hline$(\mathrm{R} \mid \mathrm{b})$ & $\mathrm{X}$ & + & $\mathrm{CH}_{2}=\mathrm{CHCH}_{3}$ & $\rightarrow$ & $\mathrm{CH}_{2} \mathrm{CH}(\mathrm{X}) \mathrm{CH}_{3}$ \\
\hline Rlc) & $X$ & 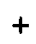 & $\mathrm{CH}_{2}=\mathrm{CHCH}_{3}$ & $\rightarrow$ & $\mathrm{HX}+\mathrm{CH}_{2}$ \\
\hline
\end{tabular}

The haloacetone product is then produced as follows.

(R2) $\mathrm{XCH}_{2} \mathrm{CHCH}_{3}+\mathrm{O}_{2} \rightarrow \mathrm{XCH}_{2} \mathrm{CH}\left(\mathrm{O}_{2}\right) \mathrm{CH}_{3}$

(R3) $\mathrm{XCH}_{2} \mathrm{CH}\left(\mathrm{O}_{2}\right) \mathrm{CH}_{3}+\mathrm{NO} \rightarrow \mathrm{NO}_{2}+\mathrm{XCH}_{2} \mathrm{CH}(\mathrm{O}) \mathrm{CH}_{3}$

(R4) $\mathrm{XCH}_{2} \mathrm{CH}(\mathrm{O}) \mathrm{CH}_{3}+\mathrm{O}_{2} \rightarrow \mathrm{HO}_{2}+\mathrm{XCH}_{2} \mathrm{C}(\mathrm{O}) \mathrm{CH}_{3}$

For chlorine atoms, approximately 10-15\% abstract a hydrogen from carbon 3 to form $\mathrm{HCl}$ [Lee et al., 1977], while the rest add to either carbon 1 or carbon 2 to form, among other products, chloroacetone and 2-chloropropanal, respectively. It has been shown that the yield of chloroacetone is of the order of $40 \%$ [Kleindienst et al., 1989]. The mechanism is similar for bromine atoms, although abstraction does not occur. The bromoacetone product yield is unknown to date but is currently being determined in our laboratory. However, detailed knowledge of the reaction yields is not necessary if the photoactive halogen detector is calibrated with known concentrations of $\mathrm{Cl}_{2}$ and $\mathrm{Br}_{2}$. In this system, calibration gases can be input at the reaction cell inlet followed by determination of the mixing ratio of the haloacetone product. It is only necessary that the product yields are invariant to input sample conditions (e.g., humidity). Air from the reaction cell is sampled by pumping the air, at $600 \mathrm{~mL} / \mathrm{min}$, through two tubes in series packed with $30 \mathrm{mg}$ of PoraPak Q (copolymer of styrene and divinylbenzene; Chrompak) to trap the chloroacetone and bromoacetone products. Extensive experiments have indicated that for $30 \mathrm{mg}$ tubes held at $\sim 0^{\circ} \mathrm{C}, 36 \mathrm{~L}$ of air can be sampled with complete trapping of chloroacetone and bromoacetone. The two tubes in series ensure that this is the case and enable testing of "breakthrough" of the analytes. After sample collection, the tubes are extracted with $100 \mu \mathrm{L}$ of glass-distilled benzene (Caledon Lab). Analysis is typically done immediately after extraction, but tests have shown both chloroacetone and bromoacetone to be stable in solution for at least several days. The products chloroacetone and bromoacetone were found to be stable on the PoraPak tubes for at least 19 hours. Sampling rates are controlled by mass flow controllers, and Gast diaphragm pumps are used to pump air through the photoactive halogen detector and sample tubes. The extracts are analyzed for chloroacetone and bromoacetone using a Hewlett Packard 5890 series II gas chromatograph equipped with a Supelco VOCOL $60 \mathrm{~m} \times 0.25 \mathrm{~mm} \times 1.5 \mu \mathrm{m}$ film thickness column and an electron capture detector. A $1 \mu \mathrm{L}$ extract sample is injected using a $2 \mu \mathrm{L}$ syringe and a splitless mode of operation because of the extremely low solution concentrations. The column is temperature programmed from $50^{\circ} \mathrm{C}$ to $100^{\circ} \mathrm{C}$ at $1{ }^{\circ} \mathrm{C} / \mathrm{min}$, then at $30^{\circ} \mathrm{C} / \mathrm{min}$ to $240^{\circ} \mathrm{C}$. A mixture of $5 \%$ methane and $95 \%$ argon (P5) is used as the carrier gas. Calibration of the gas chromatograph is done on a regular basis with dilute liquid standards of chloroacetone (Aldrich) and bromoacetone (prepared according to Blatt [1950]) in benzene. The bromoacetone is prepared by adding equimolar concentrations of acetone and bromine to a round bottom flask containing water and glacial acetic acid. The oil which separates is collected, dried, and fractionated. A pure product is obtained with subsequent distillation.

$\mathrm{Cl}_{2}$ and $\mathrm{Br}_{2}$ used for the PHD calibration are generated from VICI Metronics 140-662-002 (25 $\pm 50 \% \mathrm{ng} / \mathrm{min})$ and 110-010$0003(37 \pm 10 \% \mathrm{ng} / \mathrm{min})$ permeation cells, respectively. The cells are contained in specially designed Teflon tubes, which are contained together in a stainless steel holder. Heat tape surrounds the unit, and the outputs of the permeation source 
devices are held constant at $30^{\circ} \mathrm{C}$ using a Love (model 1600) temperature controller. The permeation rates are determined using the hydrolysis/ion chromatography method described by Keene et al. [1993]. Typically, $1 \mathrm{~L} / \mathrm{min}$ of clean air flows over the permeation sources into two impingers in series that contain $\sim 10 \mathrm{~mL}$ of an aqueous solution of $30 \mathrm{mM} \mathrm{HCO}_{3}{ }^{-}$and $5 \mathrm{mM}$ $\mathrm{HSO}_{3}{ }^{-}$. The mixture of $\mathrm{HCO}_{3}{ }^{-}$and $\mathrm{HSO}_{3}{ }^{-}$quantitatively converts $\mathrm{Cl}_{2}$ and $\mathrm{Br}_{2}$ to their corresponding ions (e.g., $2 \mathrm{Cl}^{-}$for each $\mathrm{Cl}_{2}$ ). After a specified sampling time, the measured volume of solution is analyzed for $\mathrm{Cl}^{-}$and $\mathrm{Br}^{-}$using a Dionex (DX-100) ion chromatograph. We obtained permeation rates for $\mathrm{Cl}_{2}$ and $\mathrm{Br}_{2}$ of $36( \pm 4) \mathrm{ng} / \mathrm{min}$ and $33( \pm 2) \mathrm{ng} / \mathrm{min}$, respectively.

\section{Results and Discussion}

\subsection{Calibration}

The photoactive halogen detector is calibrated with low concentration mixtures of $\mathrm{Cl}_{2}$ and $\mathrm{Br}_{2}$ in air. Using Figure 1 as a reference, the calibration process proceeds as follows: a mixture of clean air, $\mathrm{C}_{3} \mathrm{H}_{6}(0.5 \mathrm{ppm})$, and NO $(0.5 \mathrm{ppm})$ continuously flows at a total rate of $1 \mathrm{~L} / \mathrm{min}$ through the reaction vessel, controlled by a pump at the cell output, and a by-pass line just prior to the cell inlet. The output of the $\mathrm{Cl}_{2}$ and $\mathrm{Br}_{2}$ permeation sources is diluted with clean air to low mixing ratios $(0$ to $100 \mathrm{pptv}$ ) using a separate multiple dilution system composed of five mass flow controllers, which enables accurate sampling of a fraction of the output of the permeation sources. The $\mathrm{Cl}_{2}$ and $\mathrm{Br}_{2}$ mixture is then further diluted before entering the reaction vessel of the PHD. The chloroacetone and bromoacetone produced within the cell are collected on the adsorbent-filled sampling tubes, extracted, and analyzed. It should be noted that although our system is designed to enable sample collection in remote locations, the analysis could be done by direct GC analysis of the cell contents. The gas phase chloroacetone and bromoacetone concentrations in the cell are directly proportional to the concentrations of $\mathrm{Cl}_{2}$ and $\mathrm{Br}_{2}$ entering at the reaction cell inlet. Sample calibration curves for $\mathrm{Br}_{2}$ and $\mathrm{Cl}_{2}$ are shown in Figures 2 and 3, respectively. We note that the levels of chloroacetone and bromoacetone produced are, in the limit of only a small fraction of the halogen photolyzed, directly proportional to the $\mathrm{Xe}$ arc lamp light intensity. On the other hand, if all $\mathrm{Br}_{2}$ were quantitatively photolyzed, the slope of the calibration curve would be $2(\gamma)$, with a maximum of 2 for $\gamma=1$, where $\gamma$ is the bromoacetone yield resulting from $\mathrm{Br}$ atom reaction with propene. From Figure 2 we can see that the slope is $\sim 1.5$. This implies that under our operating conditions, most (if not all) of the $\mathrm{Br}_{2}$ is photolyzed. Under these circumstances, the system will be insensitive to changes in light intensity. If indeed all the $\mathrm{Br}_{2}$ is photolyzed, then the bromoacetone product yield is $75 \%$. In the case of chlorine, the maximum slope attainable is $2(0.4)=$ 0.8 [Kleindienst et al., 1989]. From Figure 3 the observed slope is $\sim 0.53$; thus a relatively smaller fraction of the $\mathrm{Cl}_{2}$ is photolyzed in our system. This is consistent with the values for $\mathrm{J}_{\mathrm{Br} 2}$ and $\mathrm{J}_{\mathrm{Cl} 2}$ and the $2 \mathrm{~min}$ residence time within the reaction cell. We estimate values of $J_{\mathrm{Br} 2}$ and $\mathrm{J}_{\mathrm{C} 2}$ in our system of $1.1 \times 10^{-1} \mathrm{~s}^{-1}$ and $1.5 \times 10^{-2} \mathrm{~s}^{-1}$, respectively.

\subsection{Gas Chromatography}

This method was designed to take advantage of the high sensitivity of the electron capture detector to chloroacetone and bromoacetone. GC calibrations show that the detection limit for chloroacetone and bromoacetone is of the order of $0.02 \mathrm{pmol}$ and

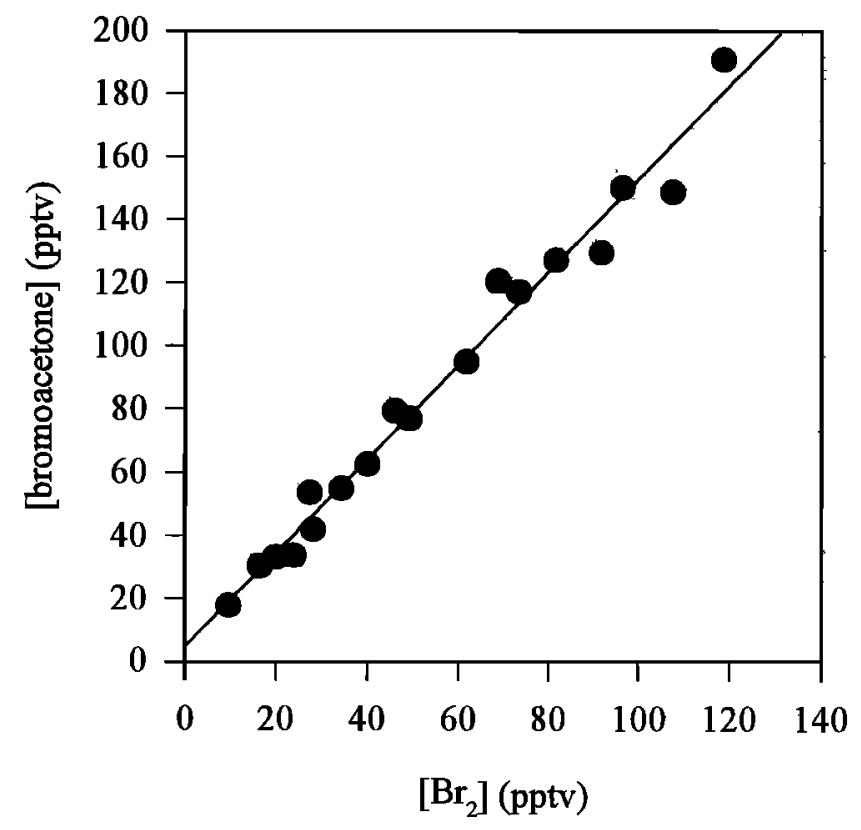

Figure 2. Photoactive halogen detector calibration for $\mathrm{Br}_{2}$ input concentrations in the range from 0 to $140 \mathrm{pptv}$. The equation of the line is given by: $Y=[1.49( \pm 0.04)] X+4.76( \pm 5.59) ; R^{2}=0.98$.

$0.01 \mathrm{pmol}$ injected, respectively. For a $36 \mathrm{~L}$ sample from the PHD, this corresponds to 1.2 pptv and 0.6 pptv as $\mathrm{Cl}_{2}$ and $\mathrm{Br}_{2}$, respectively. A typical ambient PHD sample chromatogram taken from a recent field study conducted in the Canadian Arctic at Alert, Northwest Territories $\left(82.5^{\circ} \mathrm{N}, 63.2^{\circ} \mathrm{W}\right)$, as part of the Polar Sunrise Experiment 1995, is shown in Figure 4. As shown in Figure 4, the target products are well resolved from other (presumably halogenated, e.g., $\mathrm{CHBr}_{3}$ ) species. It is thus likely that the analysis time could be significantly shortened. The resolved chloroacetone and bromoacetone peaks correspond to $100 \mathrm{pptv}$ and $20 \mathrm{pptv}$ of chlorine and bromine, respectively. Ambient mixing ratios of "total photolyzable chlorine" varied from $<9$ to 100 pptv and those of "total photolyzable bromine" varied from $<4$ to $38 \mathrm{pptv}$ over the course of the study [Impey et al., this issue].

\subsection{Blanks and Detection Limits}

Blank samples are generated using the same flows throughout the detector, with the lamp on, but no $\mathrm{Cl}_{2}$ or $\mathrm{Br}_{2}$ entering the system. Estimation of the detection limit for a measurement was calculated using the standard deviation (SD) from the total number of blank determinations. The average $\mathrm{SD}_{\text {blank }}$ for $\mathrm{Cl}_{2}$ is $3.1 \mathrm{ppt}$ and for $\mathrm{Br}_{2}$ is $1.3 \mathrm{ppt}$. The detection limit at the $99.7 \%$ confidence level can then be expressed as $3 \times$ SD blank or $9 \mathrm{pptv}$ $\mathrm{Cl}_{2}$ and $4 \mathrm{pptv} \mathrm{Br}_{2}$. This could be improved by increasing the gas phase sample volume. To date, we have been limited to a $36 \mathrm{~L}$ sample as a result of chloroacetone breakthrough from the PoraPak sample tubes. For field measurements, two types of blank samples were obtained, specifically involving either having the lamp on with zero air added at the inlet, or having the lamp off with ambient air. These blank samples exhibit bromo- and chloro-acetone concentrations that are typically much lower than for ambient or calibration samples; that is, we see little evidence for problems with carry over of photolyzable species or of the analyte chloro- and bromo-acetone on the walls. 


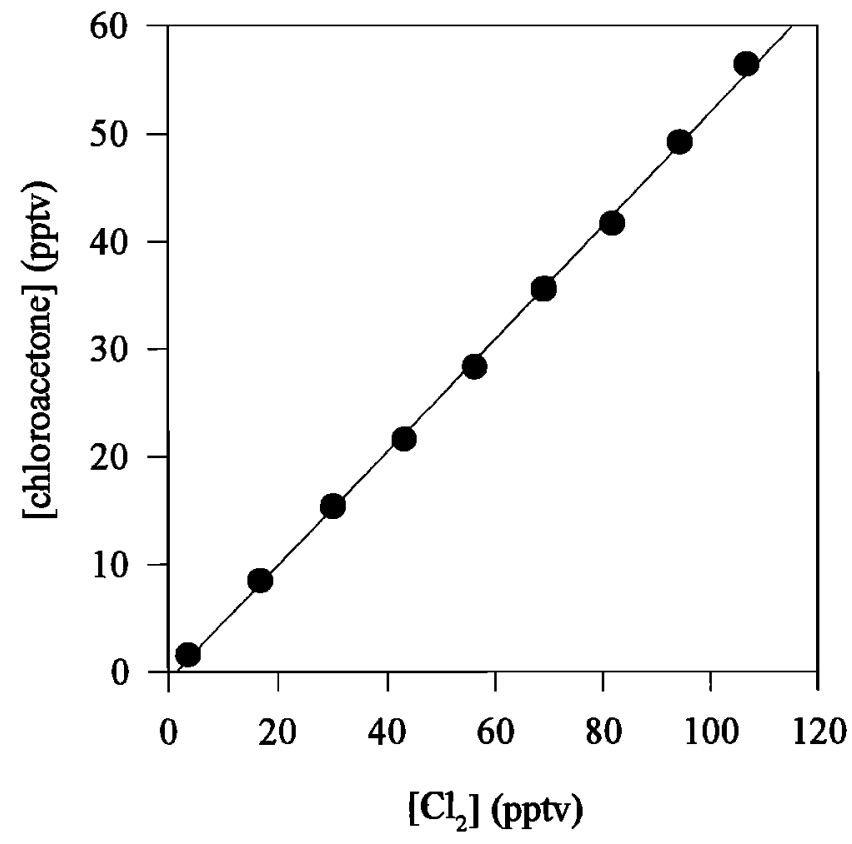

Figure 3. Photoactive halogen detector calibration for $\mathrm{Cl}_{2}$ input concentrations in the range from 0 to $120 \mathrm{pptv}$. The equation of the line is given by $Y=[0.53( \pm 0.01)] X-0.71( \pm 2.35) ; R^{2}=0.99$.

\subsection{Method Uncertainty}

Although this method yields accurate and reproducible results for a known individual photolytically active species such as $\mathrm{Br}_{2}$, there can be very large effective systematic errors in the determination of an absolute concentration if there are unknown photolytically active species present. The PHD will respond to a variety of atmospheric halogen-containing photolytically active species, e.g., in the case of $\mathrm{Br}_{\mathrm{p}}: \mathrm{Br}_{2}, \mathrm{HOBr}, \mathrm{BrNO}, \mathrm{BrNO}_{2}$, $\mathrm{BrONO}_{2}$, and $\mathrm{CHBr}_{3}$. This latter group represents the brominated species that have been suggested as precursors to $\mathrm{Br}$ atom production for the Arctic. Table 1 shows the equivalent relative concentration for each of these species that would produce the same amount of chlorine and bromine atoms as produced by $\mathrm{Br}_{2}$ and $\mathrm{Cl}_{2}$; that is, Table 1 indicates the relative concentration of each species that would produce the same measured response as do $\mathrm{Cl}_{2}$ and $\mathrm{Br}_{2}$. For example, $100 \mathrm{ppt}$ of $\mathrm{CHBr}_{3}$ is required to produce the same signal as obtained for 1 ppt of $\mathrm{Br}_{2}$. If we consider the $4 \mathrm{pptv}$ "as $\mathrm{Br}_{2}$ " detection limit, this would correspond to a 400 pptv detection limit for $\mathrm{CHBr}_{3}$. Thus it is very unlikely that $\mathrm{CHBr}_{3}$ would contribute to the overall response in the Arctic, where $\mathrm{CHBr}_{3}$ mixing ratios are typically of the order of 1-5 ppt [Yokouchi et al., 1994].

If the exact nature of the photolytically active specie(s) is known, we can estimate the overall uncertainty for this method. Variabilities in a number of factors which include blank levels, measurement of air volumes, analyte collection efficiencies, and inlet losses and calibrations influence the overall combined uncertainty of the method. For the case of $\mathrm{Cl}_{2}$ and $\mathrm{Br}_{2}$, the uncertainties are as follows. Equation (1) shows the propagation of errors in calculating the $\mathrm{Cl}_{2}$ concentration entering the reaction vessel for a calibration sample:

$($ Perm. Rate $\pm 10 \%) \times($ Dilution Factor $\pm 2 \%) \times K_{1}=$

$$
\left[\mathrm{Cl}_{2}\right] \text {,ppt }( \pm 10 \%)
$$

where $K_{1}$ is a constant which includes the molecular weight (for $\mathrm{Cl}_{2}$ or $\mathrm{Br}_{2}$ ), Avogadro's number, and the number density at STP. Dilution flow rates have uncertainties of the order of $\pm 1-2 \%$; therefore, as shown, the biggest contributor to the standard uncertainty is the uncertainty in the outputs of the $\mathrm{Cl}_{2}$ and $\mathrm{Br}_{2}$ permeation sources, which is known to be $\pm 10 \%$. The second part of the calibration involves measurement of the chloroacetone produced:

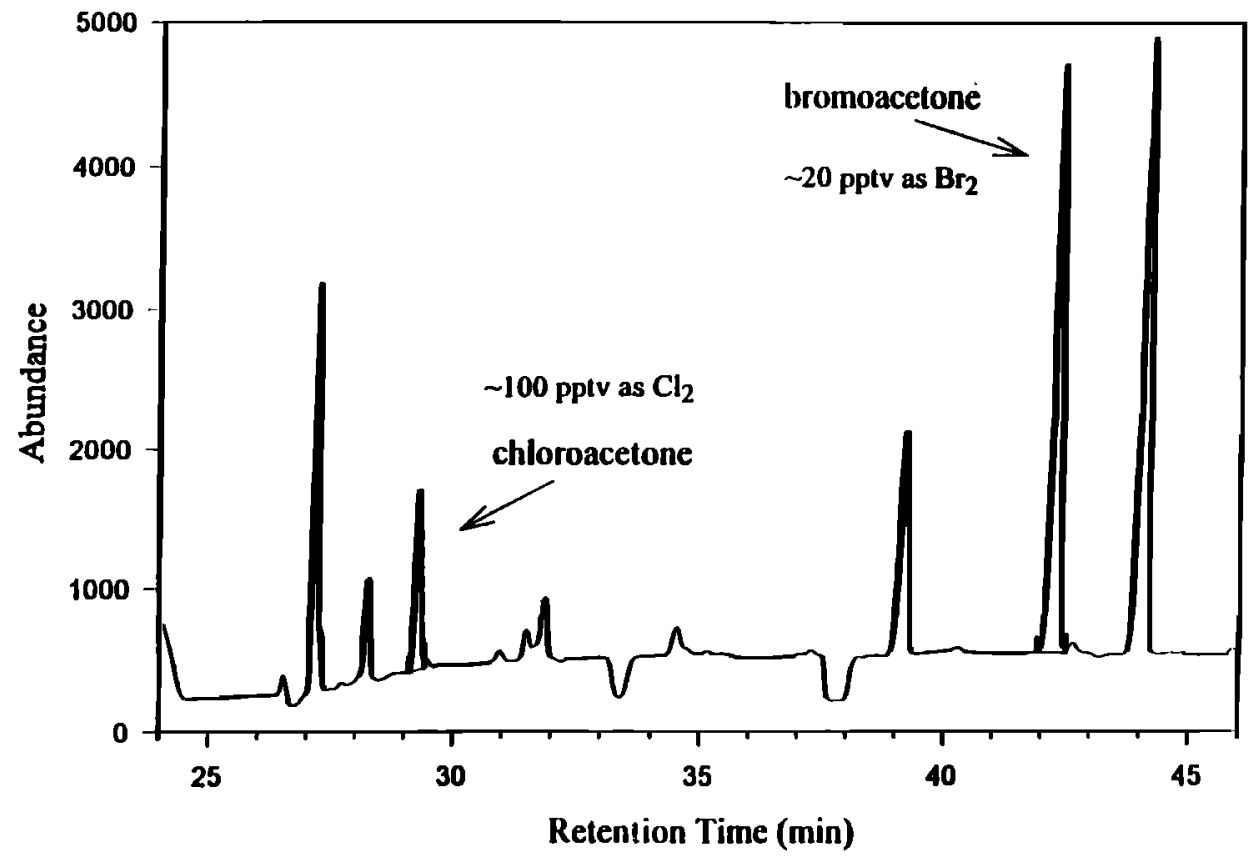

Figure 4. Ambient sample chromatogram taken on March 15, 1995 at 1041 LT during the Polar Sunrise Experiment at Alert, Northwest Territories, Canada. The resolved chloroacetone and bromoacetone peaks correspond to $100 \mathrm{pptv}$ and $20 \mathrm{pptv}$ of chlorine and bromine, respectively. 
Table 1. Estimated Equivalent Concentrations of Chlorine and Bromine Species Under Current Cell Conditions

\begin{tabular}{lccc}
\hline Cl Species & $\begin{array}{c}\text { Equivalent } \\
\text { Concentration }\end{array}$ & Br Species & $\begin{array}{c}\text { Equivalent } \\
\text { Concentration }\end{array}$ \\
\hline$\left[\mathrm{Cl}_{2}\right]$ & {$\left[\mathrm{Cl}_{2}\right]$} & {$\left[\mathrm{Br}_{2}\right]$} & {$\left[\mathrm{Br}_{2}\right]$} \\
{$[\mathrm{HOCl}]$} & $5.0\left[\mathrm{Cl}_{2}\right]$ & {$[\mathrm{HOBr}]$} & $3.4\left[\mathrm{Br}_{2}\right]$ \\
{$[\mathrm{ClNO}]$} & $2.2\left[\mathrm{Cl}_{2}\right]$ & {$\left[\mathrm{BrNO}^{2}\right]$} & $2.0\left[\mathrm{Br}_{2}\right]$ \\
{$[\mathrm{ClNO} 2]$} & $4.2\left[\mathrm{Cl}_{2}\right]$ & {$\left[\mathrm{BrNO}_{2}\right]$} & $2.0\left[\mathrm{Br}_{2}\right]$ \\
{$\left[\mathrm{ClONO}_{2}\right]$} & $20.0\left[\mathrm{Cl}_{2}\right]$ & {$\left[\mathrm{BrONO}_{2}\right]$} & $3.1\left[\mathrm{Br}_{2}\right]$ \\
& & {$\left[\mathrm{CHBr}_{3}\right]$} & $100.0\left[\mathrm{Br}_{2}\right]$ \\
\hline
\end{tabular}

$$
\begin{gathered}
\frac{(\text { Area Counts } \pm 2 \%)}{(\text { GC Calibration Slope } \pm 3 \%)} \times\left(K_{2} \pm 3 \%\right)= \\
{[\text { Haloacetone } \pm 5 \%] \text { ppt }}
\end{gathered}
$$

where, again, $K_{2}$ is a constant which includes the solvent extraction volume $( \pm 2 \%)$, Avogadro's number, the air number density, and the volume of air sampled $( \pm 2 \%)$. In equation (2) the resulting percentage uncertainty is $5 \%$. The individual blank sample determinations also carry a $\pm 5 \%$ uncertainty; however, the actual blank uncertainty depends mostly on the variability of the actual blank levels of [haloacetone] in the reactor. Therefore the combined uncertainty in the determination of the [haloacetone] that is produced must take into account the standard deviation of a series of blank determinations. Typically, the blank correction is important only near the method detection limit. For ambient samples collected in the field, the reactor haloacetone concentration (blank subtracted) is determined first using equation (2), and the resulting halogen concentration is obtained by substitution into the appropriate PHD calibration equation:

$$
\frac{\text { chloroacetone } \pm 5 \%-\text { intercept } \pm X}{\text { slope } \pm Y}=\left[\mathrm{Cl}_{2}\right] \pm Z \text { ppt }
$$

Here the uncertainty in the slope contains a contribution from the uncertainty in the permeation source output, i.e. from equation (1). For samples near the detection limit, the largest contributions to the overall uncertainty are derived mostly from the calibration slope and intercept uncertainties, rather than the $5 \%$ uncertainty from the GC determination. From the recent field study conducted in Alert, Northwest Territories, Canada, the combined uncertainties in the measured concentrations for $\mathrm{Cl}_{\mathrm{p}}$ and $\mathrm{Br}_{\mathrm{p}}$ range from 10 to $35 \%$ and 15 to $100 \%$, respectively, the higher uncertainty corresponding to levels close to the detection limit. However, these values only apply if the measured analytes are in fact $\mathrm{Cl}_{2}$ and $\mathrm{Br}_{2}$.

Although this method responds to all rapidly photolyzable species and is thus a potentially useful technique for detecting their presence, it is in the same way limited for quantitative measurements when numerous such species are present simultaneously, as indicated from the information in Table 1. However, it is in principle possible to distinguish between two known species with significantly different photodissociation rate coefficients ( $\mathrm{J}$ values), e.g., $\mathrm{Br}_{2}$ and $\mathrm{HOBr}$ (or $\mathrm{Cl}_{2}$ and $\mathrm{HOCl}$ ), which are suspected of being the dominant photolytically active species in the Arctic [Fan and Jacob, 1992]. A theoretical calculation of the species photolytic lifetimes within the reaction vessel, based on the lamp spectral output and the published absorption spectra, shows that by obtaining ambient samples with different reactor residence times, two equations with two unknowns can be obtained that can enable determination of both species (e.g., $\mathrm{Br}_{2}$ and $\mathrm{HOBr}$ ). We currently operate the reactor with a $2.0 \mathrm{~min}$ residence time. We estimate that the reactor photodissociation rate coefficients for $\mathrm{Cl}_{2}$ and $\mathrm{HOCl}$ are $\mathrm{J}_{\mathrm{Cl} 2}=$ $1.5 \times 10^{-2} \mathrm{~s}^{-1}$ and $\mathrm{J}_{\mathrm{HOCl}}=3.6 \times 10^{-3} \mathrm{~s}^{-1}$. From equation (4), where $\tau$ is the residence time in the cell,

$$
\frac{\left[\mathrm{Cl}_{2}\right]_{t}}{\left[\mathrm{Cl}_{2}\right]_{0}}=e^{-J_{\mathrm{Cl}_{2} \tau}}
$$

we find that $\approx 80 \%$ of the $\mathrm{Cl}_{2}$ entering the cell is photolyzed. Similarly, we estimate that for this residence time, only $\approx 35 \%$ of the $\mathrm{HOCl}$ is photolyzed. If we then increase the residence time by a factor of 2 , to $4.0 \mathrm{~min}$, the fraction that each will photolyze changes to $97 \%$ and $58 \%$, respectively. Thus individual $\left[\mathrm{Cl}_{2}\right]$ and $[\mathrm{HOCl}]$ mixing ratios could then be determined in the field by measurement of chloroacetone at these two residence times and solving the following two equations:

$$
\begin{aligned}
\text { [chloroacetone }]_{\tau_{1}}= & \left(\left(1-e^{-J_{\mathrm{Cl}_{2} \tau_{1}}}\right) \times 2\left[\mathrm{Cl}_{2}\right]+\right. \\
& \left.\left(1-e^{-J_{\mathrm{HOCl}_{1}}}\right) \times[\mathrm{HOCl}]\right) \alpha \\
\text { [chloroacetone }]_{\tau_{2}=} & \left(\left(1-e^{-J_{\mathrm{Cl}_{2} \tau_{2}}}\right) \times 2\left[\mathrm{Cl}_{2}\right]+\right. \\
& \left.\left(1-e^{-J_{\mathrm{HOCl}_{2}}}\right) \times[\mathrm{HOCl}]\right) \alpha
\end{aligned}
$$

where $J$ represents the photodissociation rate coefficient for the respective species in the reaction cell and $\alpha$ is the yield of chloroacetone. Thus, to differentiate between $\mathrm{Cl}_{2}$ and $\mathrm{HOCl}$ in ambient samples, it is only necessary to measure the [chloroacetone] for two different reactor residence times, and solve for $\left[\mathrm{Cl}_{2}\right]$ and $[\mathrm{HOCl}]$, assuming that $J_{\mathrm{Cl} 2}$ and $J_{\mathrm{HOCl}}$ are known. We plan to conduct measurements of $J_{\mathrm{HOCl}}$ and $J_{\mathrm{HOBr}}$, after synthesis of $\mathrm{HOCl}$ and $\mathrm{HOBr}$, as described in Taylor and Bostock [1912], Kirk-Othmer [1993], Orlando and Burkholder [1995] and Maben et al. [1995], so that these four halogen atom precursors can be quantitatively measured in the atmosphere.

\section{Conclusions}

The need for measurements of rapidly photolyzable halogen atom precursors has become increasingly important to development of a better understanding of the complex chemistry of the Arctic region. In response to this need, we developed a measurement technique that may provide answers to the surface ozone depletion phenomenon found with the onset of 24 hours of daylight, as well as the more general question regarding the global importance of halogen atom chemistry in the marine boundary layer. The method developed enables measurement of photolytically active sources of $\mathrm{Br}$ and $\mathrm{Cl}$ atoms at the low parts per trillion level, and enables detection of the relative importance of $\mathrm{Br}$ and $\mathrm{Cl}$ atoms in the atmosphere. This instrument was used in a recent field study conducted in the Canadian high Arctic at Alert $\left(82.5^{\circ} \mathrm{N}, 63.2^{\circ} \mathrm{W}\right)$ as part of the Polar Sunrise Experiment 1995. The data are discussed by Impey et al. [this issue]. Ambient mixing ratios of "total photolyzable chlorine" varied from $<9$ to $100 \mathrm{pptv}$ and those of "total photolyzable bromine" from $<4$ to $38 \mathrm{pptv}$.

Acknowledgments. We thank the Natural Sciences and Engineering Research Council of Canada and the Atmospheric Environment Service for their financial support. 


\section{References}

Abbatt, J.P.D., Heterogeneous reaction of $\mathrm{HOBr}$ with $\mathrm{HBr}$ and $\mathrm{HCl}$ on ice surfaces at 228K, Geophys. Res. Lett., 21, 665-668, 1994.

Barrie, L.A., J.W. Bottenheim, R.C. Schnell, P.J. Crutzen, and R.A. Rasmussen, Ozone destruction and photochemical reactions at polar sunrise in the lower Arctic atmosphere, Nature, 334, 138-141, 1988.

Blatt, A. H. (Ed.), Organic Syntheses, collective vol. 2, p. 88, John Wiley, New York, 1950.

Fan, S.-M. and D.J. Jacob, Surface ozone depletion in Arctic spring sustained by bromine reactions on aerosols, Nature, 359, 522-524, 1992.

Finlayson-Pitts, B.J., M.J. Ezell, and J.N. Pitts, Formation of chemically active chlorine compounds by reactions of atmospheric $\mathrm{NaCl}$ particles with gaseous $\mathrm{N}_{2} \mathrm{O}_{5}$ and $\mathrm{ClONO}_{2}$, Nature, 337, 241-244, 1989.

Finlayson-Pitts, B.J., F.E. Livingston, and H.N. Berko, Ozone destruction and bromine photochemistry at ground level in the Arctic spring, Nature, 343, 622-625, 1990.

Impey, G.A., P.B. Shepson, D.R. Hastie, L.A. Barrie, and K.G. Anlauf, Measurements of photolyzable chlorine and bromine sources during the Polar Sunrise Experiment 1995, J. Geophys. Res., this issue.

Jobson, B.T., H. Niki, Y. Yokouchi, J. Bottenheim, F. Hopper, and R. Leaitch, Measurements of C2-C6 hydrocarbons during the 1992 Polar Sunrise Experiment: Evidence of $\mathrm{Cl}$-atom and $\mathrm{Br}$-atom chemistry, J. Geophys. Res., 99, 25,355-25,368, 1994.

Keene, W.C., J.R. Maben, A.A.P. Pszenny, and J.N. Galloway, Measurement technique for inorganic chlorine gases in the marine boundary layer, Environ. Sci. Technol., 27, 866-874, 1993.

Kirk-Othmer, Encyclopedia of Chemical Technology, Vol. 5, pp. 938943, John Wiley and Sons, Toronto, 1993.

Kleindienst, T.E., P.B. Shepson, and C.M. Nero, The production of chlorine atoms from the reaction of $\mathrm{OH}$ with chlorinated hydrocarbons, Int. J. Chem. Kinetics, 21, 863-884, 1989.

Lee, F.S.C., and F.S. Rowland, Thermal chlorine-38 reactions with propene, J. Phys. Chem. 81, 1222-1229, 1977.

Maben, J.R., W.C. Keene, A.A.P. Pszenny, and J.N. Galloway, Volatile inorganic $\mathrm{Cl}$ in surface air over eastern North America, Geophys. Res. Lett., 22, 3513-3516, 1995.
McConnell, J.C., G.S. Henderson, L.A. Barrie, J. Bottenheim, H. Niki, C.H. Langford, and E.M. Templeton, Photochemical bromine production implicated in Arctic boundary-layer ozone depletion, Nature, 355, 150-152, 1992.

Orlando, J.J., and J.B. Burkholder, Gas-phase UV/visible absorption spectra of $\mathrm{HOBr}$ and $\mathrm{Br}_{2} \mathrm{O}$, J. Phys. Chem., 99, 1143-1150, 1995.

Pszenny, A.A.P., W.C. Keene, D.J. Jacob, S. Fan., J.R. Maben, M.P. Zetwo, M. Springer-Young, and J.N. Galloway, Evidence of inorganic chlorine gases other than hydrogen chloride in marine surface air, Geophys. Res. Lett., 20, 699-702, 1993.

Taylor, R.L., and C. Bostock, Researches on bleaching powder, II, The action of dilute acids on bleaching powder, J. Chem. Soc., 101, 444$457,1912$.

Vogt, R., P. J. Crutzen, and R. Sander, A mechanism for halogen release from sea-salt aerosol in the remote marine boundary layer, Nature. 383, 327-330, 1996.

Yokouchi, Y., H. Akimoto, L.A. Barrie, J.W. Bottenheim, K. Anlauf, and B.T. Jobson, Serial gas chromtographic/mass spectrometric measurements of some volatile organic compounds in the Arctic atmosphere during the 1992 Polar Sunrise Experiment, J. Geophys. Res., 99, 25,379-25,390, 1994.

L. A. Barrie, Atmospheric Environment Service, 4905 Dufferin St., Downsview, Ontario, Canada M3H 5T4. (e-mail: len.barrie@ec.gc.ca)

D. R. Hastie and G. A. Impey, Department of Chemistry, York University, Room $124 \mathrm{CCB}, 4700$ Keele St., North York, Ontario, Canada M3J 1P3. (e-mail: hastie@yorku.ca; impey@yorku.ca)

P. B. Shepson, Department of Chemistry, Purdue University, 1393 Brown Bldg., West Lafayette, IN 47907-1393. (e-mail: pshepson@chem.purdue.edu)

(Received September 27, 1996; revised February 19, 1997; accepted March 7, 1997.) 